\title{
WORLD WAR I AND TURKESTAN: SOME INFORMATION ABOUT CAPTURED TURKISH SOLDIERS
}

\section{Zumrad Rakhmonqulova}

Associate Professor Faculty Of History National University Of Uzbekistan Tashkent, Uzbekistan

\section{ABSTRACT}

The Turkish soldiers captured by Tsarist Russia in the First World War, like the people of Turkestan, were mobilized to work in the rear. There will be a brotherhood between them and the workers from Turkestan. When the war ended, the captured Turkish soldiers tried to return to their homeland from Russia via Central Asia. Among the captured Turkish soldiers were many intellectuals, some of whom came to Central Asia. They teach in schools and madrassas in Tashkent, Fergana, Andijan, Samarkand, Khiva and Bukhara.

KEYWORDS: - Usuli Jadid, First World War, Tashkent, Fergana, Andijan, Samarkand, Khiva and Bukhara.

\section{INTRODUCTION}

While getting acquainted with the documents in the Central State Archive of Cinematography of the Republic of Uzbekistan, a historical photo caught our attention. It read, "Turkish soldiers captured by Tsarist Russia during World War I." In our opinion, this photo was taken in Turkestan. We were very interested in their personalities, the situation in the country, their future. Unfortunately, very little is known about them in the available literature and sources. Perhaps enough information can be found in Turkey. Although we were not able to identify the captured Turkish soldiers in the photo, we decided to write about them using the available information. Perhaps in this photo you can meet some of the captured Turkish soldiers whose names are given below.
The ideological influence that came to Central Asia from Turkey in the late 19th century was widespread among intellectuals in the early 20th century. The influence of socio-political, cultural and ideological ideas and movements in Turkey on the emergence and development of Jadidism in Turkestan was strong. Influenced by the positive reforms being carried out by Turkish intellectuals studying in Turkey, the advanced European way of life, technical progress, culture, and enlightenment, they envied it and tried to make similar changes in their homeland [1]. It should be noted that their experiments were not mechanically copied by the Turkestan Jadids.

At the beginning of the 20th century, literature published in Crimea, Kazan and Istanbul, one of the centers of enlightenment of the Turkic world, was widely spread in Turkestan. Branches of social organizations such as the Istanbul-based 
CURRENT RESEARCH JOURNAL OF HISTORY 2(11): 58-62, November

2021

DOI: https://doi.org/10.37547/history-crjh-02-11-12

ISSN 2767-472X

(C2021 Master Journals

Crossref do

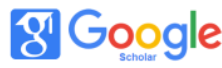

Accepted 25th November, 2021 \& Published $30^{\text {th }}$ November, 2021

"Charity Society" and "publishing" companies have been set up in Turkestan. During this period, "Usuli Jadid" schools became widespread in Turkestan.

In the early twentieth century, the peoples of Central Asia were closely watching the political changes in Turkish society. These changes in Turkey have been discussed in Bukhara, even in markets and caravanserais [3].

\section{THE MAIN FINDINGS AND RESULTS}

During the First World War, the Jadids in Turkestan did not hide their kindness to the Turks and did not stop providing material and moral support to Turkey. Documents of the Turkestan Regional Department of Defense state that large-scale fundraising for Turkey is taking place in Turkestan [4].

"Sadoyi Turkiston" and "Vaqt" newspapers regularly reported on the course of the First World War. In these press pages, one could read articles about Turkish soldiers fighting valiantly.

The battles on the Caucasus front in 1914-1917 brought failures to Turkey. About 8,000 Turkish soldiers will be captured by Russian troops in the battle of Erzurum [5].

Turkish soldiers captured by Tsarist Russia in World War I, like the people of Turkestan, were mobilized to work behind the front lines. There will be a brotherhood between them and the laborers from Turkestan. When the war is over, the captured Turkish soldiers try to return to their homeland from Russia via Central Asia. Among the captured Turkish soldiers were many intellectuals, some of whom came to Central Asia. They teach in schools and madrassas in Tashkent, Fergana, Andijan, Samarkand, Khiva and Bukhara.

One such Turkish soldier is Roji Chakirouz. He was wounded in a battle in the Caucasus, captured by the Tsarist Russian army, and sent to a camp in Krasnoyarsk. He escaped from the camp and came to Turkestan, where he taught for several years [6]. In his Memoirs, he provides important information about the political situation in Turkestan in 1918-1923 and his life in the country.

Roji Chakirouz came to Tashkent in early 1918. When he arrived in Tashkent, he found and met the addresses of fellow Turkish soldiers Ziyobey, artilleryman Haydar Shavkiy, captain Golibbey, captain Shukri, Suleyman Somi, assubay (junior soldier) Sayyid Ahrori.

According to Roji Chakirouz, Haydar Shavkiy worked in Tashkent at the 1st "Namuna", Captain Galibbey at the 6th "Turon", Captain Shukribey at the 2nd "Mukhtoriyat", Sayid Ahrori at the 10th Irfon, and Said Jamal Farobi at the Bukhara Music School. In his Memoirs, Roji Chakirouz mentions the names of some of the captured Turkish soldiers. He writes that he saw his friend Mehmet Agustosli, who escaped from the camp, at the Turkish embassy in Tbilisi.

According to Roji Chakirouz, his friend Mehmedbey was in a coma. As soon as he was discharged from the hospital, we tried to continue on our way, but the news that the Ashgabat road was closed stopped us."[7] As a result, he worked as a teacher at the newly opened 6th school "Turon" in Tashkent, then in Bukhara at the Sitorai Mohi Xosa Palace, at the Farobi Music School, at the Teachers' Institute in Chorjoi.

In the "Memoirs" of Zakiy Validi Dam, the issue of Turkish captives arose after my arrival in "Starlitomoq" (Sterlitomoq-1919-1922, the capital of the Autonomous Republic of Bashkortostan-Z.R.). Coming from Siberia, these captives, who had gathered between Ufa and Samara, asked us to help them return to their homeland. Under the pretext of Trotsky's own 
CURRENT RESEARCH JOURNAL OF HISTORY 2(11): 58-62, November

2021

DOI: https://doi.org/10.37547/history-crjh-02-11-12

ISSN 2767-472X

(C2021 Master Journals

\section{Crossref d}

\section{Google}

Accepted $25^{\text {th }}$ November, 2021 \& Published $30^{\text {th }}$ November, 2021

military needs, I helped to take wagons with one hundred and twenty seats each and send some of the captives to Tashkent and the other to Astrakhan "[8].

According to Roji Chakirouz, about eighty captives from Turkestan took refuge in Turkish soldiers. The captured Turkish soldiers were assisted by local people. Roji Chakirouz respectfully mentions the name of Munavvar Qori and notes that he was given financial assistance by Munavvar Qori to go to Shymkent for treatment.

Arriving in Bukhara in late 1921, Anwar Pasha Sitorai Mohi Hosada met with Turkish soldiers. Roji Chakirouz writes that Anwar Pasha is interested in where they were taken prisoner and explains the reasons for his coming to Turkestan. Roji Chakirouz also gives some information about Anvar Pasha's participation in the I Congress of Oriental Peoples in Baku in September 1920, the relations between the Bukhara People's Soviet Republic (BPSR) and Turkey.

On June 15, 1921, the government of the Bukhara People's Soviet Republic sent a letter to the Grand National Assembly of Turkey inviting them to sign an agreement on the exchange of mutual representatives. As a result, on November 3, 1921, Turkish diplomats began work in Bukhara. On January 4, 1922, Mustafa Kemal Fakhri Pasha, Speaker of the Turkish Grand National Assembly, was appointed Representative of the Government in Bukhara. In response, the Bukhara government sent representatives to Turkey. Representatives of the Bukhara People's Soviet Republic will be received by Mustafa Kemal. During the official meeting, the representatives of the Bukhara People's Soviet Republic expressed satisfaction with the meeting with Mustafa Kemal in Ankara and wished the Turkish people victory in the war of national liberation (War of Independence). Representatives of the Bukhara government will bring two swords and other valuable gifts to Turkey as gifts. One of the swords was sent to Mustafa Kemal, and the other was sent to liberate Izmir from Greek troops in the national liberation war [11] and hand it over to the army commander who was the first to enter the city. Expressing gratitude to the representatives of Bukhara, Mustafa Kemal said: "I am pleased to meet you as the Speaker of the Turkish Grand National Assembly. I believe that with this sword sent as a gift, the Turkish army will achieve new victories"[12].

On October 6, 1922, the government of the USSR also sent a congratulatory telegram to the Turkish Grand National Assembly. On October 12,1922 , at the initiative of the governments of the Bukhara People's Soviet Republic and the Khorezm People's Soviet Republic, a rally was held on the occasion of Turkey's victory over the intervention army. The participants of the rally will send a telegram to the Speaker of the Turkish Grand National Assembly Mustafa Kemal. In it, on behalf of the five million people of the Bukhara People's Soviet Republic, the combatant congratulates the Turkish Army on its historic victory over the interventionist army. The telegram also reads: "On October 12, a large rally was held in Bukhara to congratulate you on your victory. The Hatmi Qur'an was recited at the Kalon Mosque in Minaret in memory of those who died in the battles for national liberation."[14]

Roji Chakirouz writes that in 1923 he called Turkish soldiers to teach at a Russian military school in Charjou. Zakiy Validi Togan also wrote in his Memoirs that "there were several Turkish captive officers in Khiva. The government of Pahlovon Niyaz (Polvonniyaz Hoji Yusupov (1861-1936) - Chairman of the Council of Ministers of the Khorezm People's Soviet 
CURRENT RESEARCH JOURNAL OF HISTORY 2(11): 58-62, November

2021

DOI: https://doi.org/10.37547/history-crjh-02-11-12

ISSN 2767-472X

(C2021 Master Journals

Crossref do:

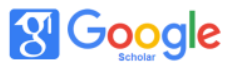

Accepted 25th November, 2021 \& Published 30th November, 2021

Republic (KhPSR) - Z.R.) brought them to Tashkent and with their help established a military school. Ridvonbek and Hasanbek from Uskudar were the leaders of this school. About a hundred Uzbeks studied in their schools. Safonov, a representative of Moscow (M. Safonov, commander of the troops of the Fergana front, was sent to the About a hundred Uzbeks studied in their schools. Safonov, a representative of Moscow (M. Safonov, commander of the troops of the Fergana front, was sent to the USSR on September 19, 1920 as an autonomous representative of the RSFSR-Z.R.) tried to close the school by dismissing Turkish officers on September 19, 1920 as an autonomous representative of the RSFSR-Z.R.) tried to close the school by dismissing Turkish officers. When the Turkish officers returned to their homeland, they treated me with great respect in Istanbul. Abdulhamid Arifov from Bukhara (Abdulhamid Aripov-BPSR Minister of Military Affairs-Z.R.) instructed the Turkish prisoners of war in Bukhara to establish a military school. Some of them organized a gendarmerie under the leadership of Ali Rizobek. Zaki Validi Dam also dwells on the activities of captured Turkish soldiers in Central Asia. In particular, Umarbek's support for the captured Turkish soldiers in Tashkent and Fergana, and Ali Riza's several letters from Anvar Pasha. According to Kahramon Rajabov, the Turkish colonel Ali Rizo Efendi was the chief of the militia of the republic (BPSR).

During this period, it was possible to meet captured Turkish soldiers in various cities of Russia. In May 1917, the first congress of Muslims of All Russia was held. In June of this year, the Muslims of Nizhny Novgorod sent a letter to the executive committee of the AllRussian Muslim Council about the situation of captured Turkish soldiers in the camp of the Nizhny Novgorod province. The letter says that
Turkish captives captured by Russian troops on the Caucasus front are living in a camp in difficult conditions.

\section{Conclusion}

The number of prisoners in the camp of Nizhny Novgorod province was about five hundred, and in a few months about two hundred soldiers died of starvation and various diseases. It is said that the townspeople are helping the captured Turkish soldiers, even though they are living in difficult conditions, including a soldier in his late 90s. [16]. The Nizhny Novgorod Muslim Council has contacted the Turkish government and asked them to help by taking measures such as arranging for the exchange of prisoners or transferring them to warmer countries.

Turkish soldiers captured by Tsarist Russia in the First World War took an active part in the socio-political and cultural life of Turkestan. They were assisted by local people in overcoming the existing difficulties.

\section{REFERENCES}

1. New history of Uzbekistan. I book. Tashkent: Sharq. 2000. -p. 260.

2. Dolimov U. Jadid schools in Turkestan. Tashkent: University. 2006.

3. Turkestan collection. Tashkent: 544. -p. 123.

4. MDA RUz, 3rd fund, 2nd list, 253 cases, 3rd sheet; MDA RUz, Fund 461, List 1, Case 2157, 15 pages.

5. Shishov A. Caucasian Front // World War I: Prologue of the XX century. Moscow:1998. -p.578-587.

6. Roji Chaqirouz. Corners close to my heart. Translated by Rustam Sharipov // World Literature. 1997. №5. B.204. 
CURRENT RESEARCH JOURNAL OF HISTORY 2(11): 58-62, November

2021

DOI: https://doi.org/10.37547/history-crjh-02-11-12

ISSN 2767-472X

(C)2021 Master Journals

\section{Crossref doi) 81 Google}

Accepted 25th November, 2021 \& Published 30 ${ }^{\text {th }}$ November, 2021

7. Roji Chaqirouz. The work shown. -p. 197.

8. Ahmad Zaki Walid Dam. Divided wolf land. Tashkent: Adolat.1997. -p. 70.

9. Roji Chaqirouz. The work shown. -p. 204.

10. Boltaboev H. Unsatisfactory revolution // Sharq yulduzi. 1991. №1. 137 b.

11. Sakarya, which was besieged from August 23 to September 13, 1921, was saved from the invasion of Greek troops. In September 1922, Izmir was also liberated. On September 18, 1922, Anatolia was liberated. Kornienko R.P. Labor movement in Turkey 1918 -1963. Moscow: 1960. -p. 40.

12. Babakhodzhaev A.Kh. Central Asia and Turkey in the years of the liberation struggle of the Turkish people against the intervention of the Entente // Social Sciences in Uzbekistan. 1961. No. 12. P. 27.

13. Babakhodzhaev A.Kh. Central Asia and Turkey in the years of the liberation struggle of the Turkish people against the intervention of the Entente // Social Sciences in Uzbekistan. 1961. No. 12. -p. 28.

14. MDA of the Republic of Uzbekistan. Fund 48, List 1, Case 81, 248 pages.

15. Ahmad Zaki Walidiy Dam. The work shown. -pp. 96-105.

16. Rajabov Q. Extinguished. There is another burning // Society and management. 1997.№2. -p. 39.

17. Faizov S.F. Letter from the Muslims of Nizhny Novgorod to the Executive Committee of the All-Russian Muslim Council about the plight of Turkish prisoners in the Nizhny Novgorod camp. Moscow: Ant. 2003. -p. 181-187.
18. Rakhmankulova ZB, Rakhmankulova MB. SOME PECULIARITIES OF THE BOOKBINDING IN TEMURID'S EPOCH. Theoretical \& Applied Science. 2019(10):266-72.

19. Rakhmankulova, Z., Choriev, S., Yusupova, D., \& Muminov, O. (2020). The Historiography Of The Relations Between Central Asian Khanates And Ottoman Empire In The 19 th And At The Beginning of The 20 th Centuries. International Journal of Scientific and Technology Research, 9(2), 311-318. 